\title{
Microbiological and physicochemical quality of some water points in the Nkolafamba Subdivision (Center Region, Cameroon)
}

\author{
O. V. NOAH EWOTI ${ }^{*}$, A. TAMSA ARFAO ${ }^{1}$, S. D. BALENG ${ }^{1}$, L. M. MOUNGANG ${ }^{1}$, \\ C. S. METSOPKENG ${ }^{1}$, R. P. TUEKAM KAYO², Y. POUTOUM YOGNE ${ }^{1}$, \\ D. EBANG MENYE ${ }^{3}$ and M. NOLA ${ }^{1}$
}

\author{
${ }^{1}$ Laboratory of Hydrobiology and Environment, Department of Animal Biology and Physiology, Faculty of \\ Science, University of Yaounde 1, PO Box 812 Yaoundé, Cameroon. \\ ${ }^{2}$ Laboratory of microbiology, Department of microbiology, Faculty of Science, University of Bamenda. \\ ${ }^{3}$ University of Maroua, Higher Teacher's Training School College, P.O Box 55 Maroua, Cameroon. \\ *Corresponding author; E-mail: noahewoti@yahoo.fr
}

\begin{tabular}{ccc}
\hline Received: 18-12-2020 & Accepted: 08-04-2021 & Published: 30-04-2021 \\
\hline
\end{tabular}

\begin{abstract}
A study was carried out with the objective of evaluating the microbiological and physicochemical quality of surface water in the Nkolafamba subdivision, Center Region of Cameroon. Five sampling points were selected based on several criteria. The bacteria isolated were Mesophilic Aerobic Heterotrophic Bacteria (BHAM), bacteria that were witnesses to faecal contamination and Pseudomonas. Some abiotic parameters were measured using the usual techniques. The results show that some physicochemical parameters such as temperature was almost constant around $25^{\circ} \mathrm{C}$ during the study period. There is also a pH which tended towards neutrality $\mathrm{pH}$ de $(7,04 \pm 1,03$ U.C). However, it was noted that the stations are quite oxygenated $(63,96 \%)$. Bacteriological analyzes revealed that an average value of 5.17 units $(\log U F C / 100 \mathrm{~mL})$ was recorded for BHAM. Overall, the abundances of total coliforms averaged 4.18 units $(\log$ UFC / 100mL). The waters of Nkolafamba also harbor a pathogenic microflora, with bacteria such as $P$. aeruginosa $P$. pasteurella, the abundance of which can sometimes reach 5,462 units $(\log \mathrm{CFU} / 100 \mathrm{~mL})$. These germs can be the cause of eye infections or septicemia on users of these waters. These waters have a high bacterial load, and the microbiological pollution observed is predominantly animal. Some abiotic parameters such as $\mathrm{pH}$, electrical conductivity, Suspended Solid (SS), nitrates and turbidity have influenced the distribution of these germs. The degradation of the quality of these waters is favoured by their proximity to sources of pollution, the runoff of contaminated water in the stations. These waters, without any treatment, are not recommended for human consumption according to the standards of the World Health Organization.

(C) 2021 International Formulae Group. All rights reserved.
\end{abstract}

Keywords: Abiotic variables, faecal coliforms, faecal streptococci, pathogenic bacteria, rivers.

\section{INTRODUCTION}

Water is an essential resource for human both for food needs and for various other uses (WHO, 2004). Yet, most of humanity does not have access to this resource. She suffers from water stress with less than $1700 \mathrm{~m}^{3}$ of fresh water available per capita / year (WHO, 2004).

Of the 13,600 million $\mathrm{km}^{3}$ of water that cover the planet, only $0.014 \%$ is fresh water usable by human as surface water (WHO, 
2004). In emerging countries in general and in Cameroon in particular, the massive resignation of the populations to use surface water (rivers, springs, etc.) is linked to the insufficient means of local municipalities to ensure an optimal distribution of drinkable water. Kueté et al. (2004) mention in this regard that these populations often face water supply problems in their distribution network. Indeed, the population explosion is causing a scarcity of sources of drinking water supply. The populations therefore, in the need to obtain drinking water, find themselves obliged to use surface water that they ignore the microbiological quality (WHO, 2004). However, this water has been qualified of dubious or contaminated quality by several studies and likely to cause many ills (Nola et al., 2010; Moungang et al., 2013). Contamination of surface waters by pathogens is a pollution problem that dates back a long time (WHO, 2004). Pollution of water from faecal microorganisms appeared very early as soon as water was used as a vector for waste disposal (George and Servais, 2002). Human contamination occurs either by consumption of drinking water, by consumption of food contaminated by water, even during bathing or contact with water for recreational use (George and Servais, 2002).

Several studies have already been carried out on the microbiological quality of water in the Yaoundé region, as well as on the role of soil in the transfer of bacteriopollutants from the soil surface to underground water. They reveal that these waters are acidic, soft and weakly mineralized (Nola et al., 2000). They harbor a varied bacterial microflora made up of fecal bacteria, commensal bacteria, and opportunistic pathogenic bacteria, whose abundance dynamics undergo spatio-temporal variations (Nola et al., 2010). The population of these microorganisms is significantly influenced by physico-chemical factors such as gas content and certain dissolved ions, and meteorological factors such as precipitation and sunstroke (Nola et al., 2000; 2002). Other analyzes took into account the lotic and lentic environments in the Center, Littoral and West Cameroon region, and made it possible to assess the state of health of these hydrosystems. Based on the structure of aquatic communities, the hydrosystems so far prospected concern, among others the Mfoundi (Foto Membohan et al., 2013) the municipal lake of Yaoundé (Zébazé Tougouet et al., 2011) the Obili lake (Ajeagah et al., 2018). This work reveals that urban and peri-urban waterways are subject to organic pollution of anthropogenic origin due to the promiscuity linked to the high density of populations in the watersheds and to the use of water bodies as receptacles of water waste.

Despite this work, very little information is available on the microbiological and physicochemical quality of the waters of the Nkolafamba subdivision, a small town located in the suburbs of the city capital and in full swing. In addition, little is known about the variation in the densities of some pathogenic bacteria present in surface waters often used by the populations that live there. Likewise, little data is available on the influence of physicochemical and hydrological factors on the variation in bacterial abundance of these rivers. The present work aimed at determining the microbiological and physicochemical quality of some rivers in the district of Nkolafamba.

\section{Collection of data \\ Geographical setting}

The city of Nkolafamba is located in the Center region of Cameroon, a suburb of the political capital Yaoundé, in the Mefou and Afamba department and in the Nkolafamba district. This small town is about $10 \mathrm{~km}$ from Yaoundé between $3{ }^{\circ} 51^{\prime} 32$ " North latitude and $11^{\circ} 39^{\prime} 53^{\prime \prime}$ East longitude. At the time of the 2005 census, Nkolafamba had 14,494 inhabitants and went back to around 40 small villages (RGPH, 2005). The climate is tropical and equatorial, with four seasons ( 2 dry and 2 rainy) of unequal duration. The average rainfall is around $1633 \mathrm{~mm}$ with average temperatures rarely exceeding $25{ }^{\circ} \mathrm{C}$ (Suchel, 1987). The hydrographic network of this area is organized around the Afamba river and its main tributaries: Mefomo, Lolo and Otoundoumba. The soils do not differ from those in the 
Yaoundé region (Vallerie, 1973). Indeed, these soils are mainly of the domain of ferralitic soils. There are nevertheless two variants, namely red, clayey and acidic ferralitic soils $(\mathrm{pH}<5.5)$ and yellow clayey ferralitic soils very rich in iron (Vallerie, 1973). Figure 1 shows the study area and the location of the sampling stations.

\section{Choice and geographic location of sampling points}

In total, 5 sampling points were selected because of the importance of the frequency of water use, the interest given by the populations to these points, the proximity of a source of pollution, the desire to cover the entire study area and access: either 2 sampling points on the Afamba river, the city's main waterway, and 1 point on each of the Mefomo, Lolo and Otoundoumba tributaries. The geographical location of each sampling point, the codes adopted, and the altitude in relation to the sea are presented in Table 1. It appears that the study was carried out between $667 \mathrm{~m}$ and 719 $\mathrm{m}$ altitude, and between $3^{\circ} 43^{\prime} 11.1$ " North latitude and $11^{\circ} 33^{\prime} 33.3^{\prime \prime}$ East longitude.

\section{Sampling and method of analysis Sampling}

A $1 \mathrm{~m} \times 1 \mathrm{~m}$ quadrat so as to delimit the exact places where the watercourse is actually used by the populations was delimited at each sampling station to carry out the sampling and measure the hydrological properties of the watercourses (Bernard and Salle, 2010). In addition to hydrological parameters, physicochemical and microbiological parameters were considered. Samples for bacteriological analyzes were carried out in sterile $500 \mathrm{~mL}$ glass vials. The water samples for the physicochemical analyzes were taken in two batches of polyethylene bottles, a bottle of $1000 \mathrm{~mL}$ where the water was introduced without making bubbles, intended for the laboratory measurement of parameters such as oxygen dissolved, turbidity, colour among others. Another $250 \mathrm{~mL}$ vial in which dissolved $\mathrm{CO}_{2}$ is fixed in the field before being determined in the laboratory by the volumetric method. All placed in a refrigerated enclosure and transported to the laboratory. The physicochemical parameters considered in this study were measured in the field and in the laboratory using the techniques recommended by Rodier et al. (2009).

\section{Analyzes of hydrological parameters Water flow velocity}

The water flow velocity (V) expressed in $\mathrm{m} / \mathrm{s}$ was measured at each station by the indirect method which consists in determining, using a chronometer, the time ( $\mathrm{t}$ in $\mathrm{s}$ ) taken by a neutral dye not pollutant (methylene blue) to travel a known distance ( $\mathrm{d}$ in $\mathrm{m}$ ), without obstacle as previously defined (Rodier et al., 2009).

\section{Wet section}

A line transect was carried out at each of the sampling stations using two stikes planted at each of the banks of the stations at the edge of the wetland. These stikes perpendicularly support a graduated horizontal string. Then, a graduated ruler immersed vertically in the water allows you to determine the respective depths of water and sludge from one bank to the other, following the graduation of the string with a step of $50 \mathrm{~cm}$. The data collected made it possible to represent and determine, by station, the area of the wetted section in $\left(\mathrm{m}^{2}\right)$ by grid on graph paper (Rodier et al., 2009).

Debit

The water flow rate expressed in $\mathrm{m}^{3} / \mathrm{s}$ and was obtained from the product of the wetted section and the speed by the formula (Rodier et al., 2009), with: flow rate in $\mathrm{m}^{3} / \mathrm{s}$, flow speed in $\mathrm{m} / \mathrm{s}$, wetted section in $\mathrm{m}^{2}$.

\section{Evaluation of physicochemical parameters}

The physicochemical parameters were analyzed by the techniques recommended by Rodier et al. (2009). All the parameters considered were temperature, $\mathrm{pH}$, conductivity, dissolved $\mathrm{O}_{2}$, suspended solids, color, turbidity, nitrates, ammoniacal nitrogen, orthophosphates and dissolved $\mathrm{CO}_{2}$.

The temperature, $\mathrm{pH}$, conductivity and dissolved $\mathrm{O}_{2}$ were measured in situ using a mercury column thermometer graduated to $1 /$ 10th of a degree Celsius, digital $\mathrm{pH}$ meter model brand SCHOTT GERATE CG 818, a portable TDS / conductivity meter from HANNA series HT 8733, and an oximeter from 
HANNA, model HI 9146; the units are expressed in ${ }^{\circ} \mathrm{C}, \mathrm{UC}, \mu \mathrm{S} / \mathrm{cm}$ and in $\% \mathrm{O}_{2}$ saturation respectively. The measurement of the dissolved $\mathrm{CO}_{2}$ content was carried out in two stages. On the field, the $\mathrm{CO}_{2}$ was fixed by introducing into a $200 \mathrm{ml}$ volumetric flask, 20 $\mathrm{ml}$ of sodium hydroxide $(\mathrm{NaOH}) \mathrm{N} / 20$ plus 2 to 3 drops of phenophthalein, this mixture was made up with the sample of raw water up to the mark. The resulting mixture of pink color was stored in a $250 \mathrm{ml}$ double-capped polyethylene flask and then returned to the laboratory. In the laboratory, $50 \mathrm{~mL}$ of this sample was titrated with $\mathrm{N} / 10$ hydrochloric acid $(\mathrm{HCl})$ until complete discoloration. The $\mathrm{CO}_{2}$ content of the water expressed in $\mathrm{mg} / \mathrm{L}$, was then determined by the formula: $\left[\mathrm{CO}_{2}\right](\mathrm{mg} / \mathrm{L})=($ control burette descent - sample burette descent) $\times$ 17.6. Table 2 shows the physicochemical parameters measured in the laboratory, the method of analysis, and the reagents used, the wavelengths $(\lambda)$ of reading with the DR / 2000 spectrophotometer.

\section{Microbiological evaluation of the rivers of the city of Nkolafamba \\ Heterotrophic Bacteria Aerobic Mesophilic}

BHAM species were isolated from the plain agar surface cast in a Petri dish by surface spreading techniques. $100 \mu \mathrm{L}$ of the sample was taken using a sterile Hamburg strainer pipette and then deposited on the agar surface. The sample was subsequently plated using a sterile glass spreader (Marshal et al., 1991). The Petri dishes are then incubated at room temperature and the readings are taken gradually over 5 days (Holt et al., 2000).

\section{Fecal and total coliforms}

Fecal and total coliforms were isolated on ENDO-specific culture media by surface spreading and membrane filter techniques. The filter membrane technique is used when the spreading on the surface is negative (Diagnostic Pasteur, 1987, Marshal et al., 1991). Readings were taken after 24 to 48 hours of incubation. Fecal coliforms were incubated at $44{ }^{\circ} \mathrm{C}$ and total coliforms at $37^{\circ} \mathrm{C}$ for 18 to 48 hours (Marshal et al., 1991). The enumeration was carried out by direct counting. (Holt et al., 2000).

\section{Fecal streptococci}

Isolation of faecal streptococci was carried out by the filter membrane technique on BEA agar (Bile Esculin Azide) at a temperature of $37^{\circ} \mathrm{C}$ and the counts were carried out after 18 to 24 hours of incubation (Marshal et al., 1991).

Characterization of potentially pathogenic bacteria (genus Pseudomonas)

-Isolation and enumeration: Pseudomonas was chosen to verify the presence of bacteria endowed with pathogenicity and responsible for immediate public health problems (Mezaache, 2012). Isolation of bacteria of the genus Pseudomonas was done by the membrane filter technique on $\mathrm{CN}$ agar (Cetrimide) at a temperature of $37^{\circ} \mathrm{C}$ for 18 to 24 hours (Marshal et al., 1991). After isolation and enumeration, strains with satisfactory cultural characteristics were collected and subjected to various other confirmatory tests.

-Biochemical identification of bacteria of the genus Pseudomonas: The identification of Pseudomonas has been based on a number of biochemical tests. After isolation of the bacteria, the colonies exhibiting the characteristics of bacteria of the genus Pseudomonas were purified by streaking on cetrimide medium. After subculture on PCA (Plate count agar) sloped and incubated at 37 ${ }^{\circ} \mathrm{C}$ for 18 to 24 hours, the biochemical tests were carried out according to the usual biochemical criteria, using the conventional gallery (Marshal et al., 1991). The tests considered were catalase, gas production, glucose utilization, lactose and mobility among others (Holt et al., 2000).

Determination of the probable origin of the microbiological contamination of the Nkolafamba Rivers

The relationship between the densities of faecal coliforms (CF) to those of faecal streptococci (SF) has made it possible to determine the probable origin of the pollution (WHO, 2004). Indeed, when $\mathrm{CF} / \mathrm{SF} \geq 4$, the pollution is probably of human origin; $2 \leq \mathrm{CF}$ / $\mathrm{SF}<4$ pollution is said to be predominantly human in a mixed population; $1<\mathrm{CF} / \mathrm{SF}<2$ pollution is probably linked to a mixed population, $0.7<\mathrm{CF} / \mathrm{SF}<1$ predominantly 
animal water pollution in a mixed population, $\mathrm{CF} / \mathrm{SF} \leq 0.7$ pollution is said to be of animal origin (WHO, 2004).

Assessment of the importance of physicochemical and hydrological variables on the microbiological distribution of rivers

To determine the impact of physicochemical and hydrological variables on the variation in microbial densities of Nkolafamba streams, spearman "r" correlation tests were performed using SPSS software. These tests were supplemented by analyzes of Mann Whitney and Kruskal Wallis comparisons between sampling periods, and between the different ones and by Principal Component Analysis (PCA).

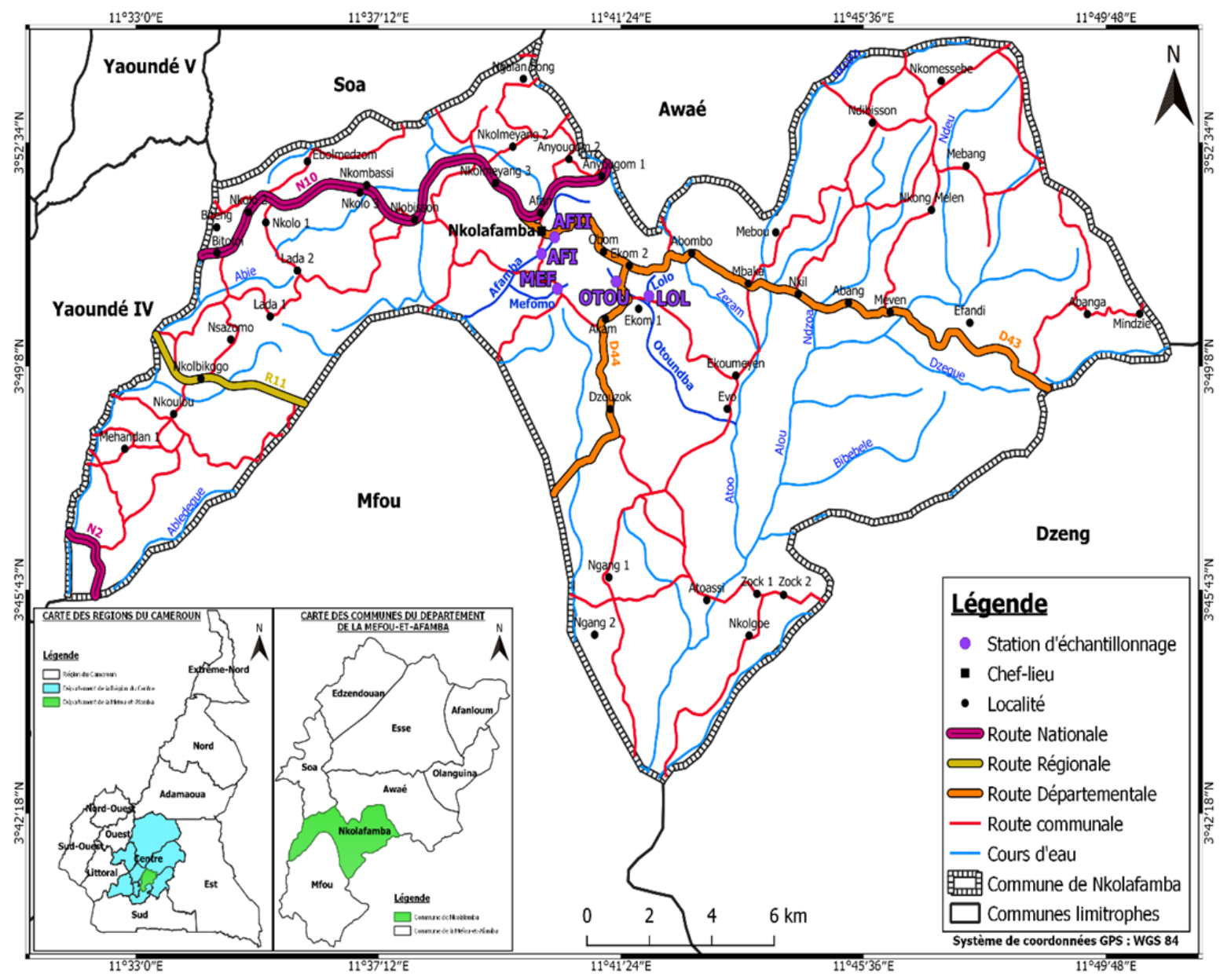

Figure 1: Presentation of the study area and the location of the sampling points.

Table 1: Geographical location, adopted code, and altitude of each sampling point.

\begin{tabular}{llll}
\hline Stations & Adopted Codes & Altitudes (m) & Geographical locations \\
\hline Afamba I & AFI & 670 & $03^{\circ} 43^{`} 16,5^{`} \mathrm{~N} 11^{\circ} 33^{`} 16,9^{`} \mathrm{E}$ \\
\hline Mefomo & MEF & 698 & $03^{\circ} 43^{`} 25,7^{`} \mathrm{~N} 11^{\circ} 33^{`} 33,3^{`} \mathrm{E}$ \\
\hline Lolo & LO & 699 & $03^{\circ} 43^{`} 16,4^{\prime} \mathrm{N} 11^{\circ} 33^{`} 20,2^{` `} \mathrm{E}$ \\
\hline Afamba II & AFI & 667 & $03^{\circ} 43^{`} 12,3^{`} \mathrm{~N} 11^{\circ} 33^{`} 21,9^{`} \mathrm{E}$ \\
\hline Otoundoumba & OTOU & 719 & $03^{\circ} 43^{`} 11,1^{`} \mathrm{~N} 11^{\circ} 33^{`} 28,5^{`} \mathrm{E}$ \\
\hline
\end{tabular}


Table 2: Physicochemical parameters measured in the laboratory by spectrophotometer.

\begin{tabular}{|c|c|c|c|c|}
\hline Parameters & Method & Reagents used & $\lambda(\mathbf{n m})$ & Units \\
\hline SS & \multirow{5}{*}{ Spectrophotometry } & - & 810 & $\mathrm{mg} / \mathrm{L}$ \\
\hline Color & & - & 455 & $\mathrm{Pt} / \mathrm{Co}$ \\
\hline Turbidity & & - & 450 & FTU \\
\hline Nitrate $\left(\mathrm{NO}_{3}^{-}\right)$ & & NitraVer IV & 570 & $\mathrm{mg} / \mathrm{L}$ \\
\hline Phosphate $\left(\mathrm{PO}_{4}{ }^{3-}\right)$ & & PhosVer & 880 & $\mathrm{mg} / \mathrm{L}$ \\
\hline
\end{tabular}

\section{RESULTS}

\section{Analyzes of hydrological variables Water flow velocity}

The highest value of the water flow velocity is recorded at the OTOU station $(0.33 \mathrm{~m} / \mathrm{s})$ followed respectively by $\operatorname{MEF}(0.22$ $\mathrm{m} / \mathrm{s}), \operatorname{AF}$ II $(0.155 \mathrm{~m} / \mathrm{s}), \mathrm{LO}(0.153 \mathrm{~m} / \mathrm{s})$ and AF II $(0.124 \mathrm{~m} / \mathrm{s})$ (Table 3$)$.

\section{Wet section}

The wetted section is calculated by the product of the bed width and the average water depth. It varied during the study between 0.84 $\mathrm{m}^{2}$ obtained at LO level and $5.22 \mathrm{~m}^{2}$ recorded at OTOU. The beds of the five stations are covered with a significant amount of mud and the banks with phanerogam vegetation. Sludge depth was not taken into account because the area is free from industries that could release heavy metals into waterways. Figure 2 shows the bed widths and water depths obtained during the study period.

\section{Flow rate}

The maximum value was obtained at OTOU $\left(1.76 \mathrm{~m}^{3} / \mathrm{s}\right)$ and the minimum value is obtained at the level of LO $\left(0.128 \mathrm{~m}^{3} / \mathrm{s}\right)($ Table $3)$.

\section{Evaluation of physicochemical parameters Physical parameters (MES, Temperature, Turbidity, Colour and TDS)}

The physical parameters considered during this study varied throughout from campaign to campaign and from station to station and from sampling point to sampling point. The SM values obtained during the study period varied between $0 \mathrm{mg} / \mathrm{L}$ (April, Afambal station) and $46 \mathrm{mg} / \mathrm{L}$ (June at the
Lolo station) (Figure 3A). Solids content fluctuates around an average value of $19.48 \pm$ $14.32 \mathrm{mg} / \mathrm{L}$. The measured temperature values fluctuated between 23 and $28{ }^{\circ} \mathrm{C}$. The highest value was recorded at the station on Mefomo in March. And the lowest value at the station on the Lolo in June. However, an average value of $25.48 \pm 1.354{ }^{\circ} \mathrm{C}$ is noted (Figure 3B). The highest value for turbidity (97 FTU) was recorded in February at the station on the Lolo. The lowest value (34 FTU), was recorded in June at the same station (Figure 3C) with an average value of $59.933 \pm 14.359$ FTU. Overall, the water color values hovered between 22 and $437 \mathrm{Pt}$.Co with an average value of $117.96 \pm 89.75$ Pt.Co. The lowest value was recorded at Afamba1 and Otoundoumba stations in April and the highest value was recorded at the Lolo station in February (Figure 3D). The TDS values recorded during the study period varied between 15 and $87 \mathrm{mg} / \mathrm{L}$. The highest value was obtained for the station on Lolo in March and the lowest value was recorded at the station on Mefomo in February. However, an average value of $27.266 \pm 17.05 \mathrm{mg} / \mathrm{L}$ is noted (Figure 3E).

\section{Chemical parameters}

Overall, dissolved $\mathrm{CO}_{2}$ values ranged from 0.2 to $7.04 \mathrm{mg} / \mathrm{L}$. The highest value was recorded at Afamba1 station in June. The lower value was obtained at the station on Mefomo in June. However, an average value of 3,802 \pm $1,491 \mathrm{mg} / \mathrm{L}$ is noted (Figure 4A). The dissolved oxygen contents fluctuated between 50.5 and $75.3 \%$. They reached their maximum value at the station on Mefomo in March and 
the minimum value was recorded at Afamba1 station in March and April. An average value of $63.96 \% \pm 8.468$ was noted (Figure 4B). Ammoniacal nitrogen levels are found in the water in the form of traces with levels between $0.09 \mathrm{mg} / \mathrm{L}$ (in February at the station on the Mefomo) and $1.8 \mathrm{mg} / \mathrm{L}$ (in July at the station on Otoundoumba) (Figure 4C). The $\mathrm{pH}$ values fluctuated overall between 5.8 and $8.91 \mathrm{UC}$ The highest value was obtained at the station on Mefomo in February and the lowest value at the station on Otoundoumba in July (Figure 4D). Nitrate levels are highest in April at Afamba 2 station $(20.8 \mathrm{mg} / \mathrm{L})$. The lowest $(0.5$ $\mathrm{mg} / \mathrm{L}$ ) at the Afamba 1 station in March (Figure 4E). The electrical conductivity values oscillated between 32 and $173 \mu \mathrm{s} / \mathrm{cm}$. The highest value was recorded at the station on the Lolo in February and June. The lowest value at Afamba 2 station in May (Figure 4F). The levels of orthophosphates in water show irregular variations, with values reaching 21.9 $\mathrm{mg} / \mathrm{L}$ in March, at the station on the Mefomo. They were scarce throughout the month of April in the Afambal station (Figure 4G).

\section{Microbiological analyzes of sampled water}

Overall, the abundances of BHAM, faecal and total coliforms, faecal enterococci varied from station to station and during each campaign (Figure 10). In general, BHAMs were most abundant at all stations throughout the study period (Figure 5A). BHAM densities fluctuated between 4.36 and 6.03 units (log CFU / 100mL water). The lowest abundance was obtained at station AF1 in July and the highest abundance at the station on the Lolo during June. As for the total coliforms, their density varied from 3.69 to 5.71 units ( $\log \mathrm{CFU}$ / $100 \mathrm{~mL}$ of water). The smallest value of 3.69 units (log CFU / 100mL)

\section{Determination of the origin of microbiological pollution of water}

The probable origin of the pollution was determined from faecal coliform to faecal streptococci (CF / SF) ratios (Table 4). The reports having thus been established by sampling station and by month, it can be seen that the pollution is predominantly of animal origin in the Afamba1 stations during the months of February, April, May, June, July; Mefomo during all the months of the sampling campaign except June, Lolo during the months of February, March, April, June; Afamba 2 during every month and in Otoundoumba during the months of February, March, May and July. Microbial pollution is linked to a mixed population in Mefomo stations in April, Lolo during the months of May and July and in Otoundoumba station in June. Cases of pollution probably linked to human origin were not observed throughout our sampling campaign.

\section{Assessment of the presence of a pathogenic species (genus Pseudomonas) \\ Qualitative analysis}

Macroscopic examination of bacterial colonies on Cetrimide Agar showed three types. Small-sized white colonies, mediumsized white colonies, and large-sized white colonies fluorescent under ultraviolet radiation were observed. The results of the biochemical examinations carried out are presented in Table 5. It appears that the waters of the rivers analyzed mainly harbor $P$. aeruginosa and $P$. maltophilia.

\section{Quantitative analysis}

The densities of Pseudomonas colonies vary during the study period depending on the site and month of sampling. The highest value (5.462 log CFU / 100mL) and the lowest value (3.39 log CFU / 100mL) were recorded respectively in the AF II station in February and April respectively (Figure 6).

\footnotetext{
Assessment of the impact of hydrological and physicochemical parameters on the variation of microbial densities Correlations between hydrological variables and bacterial densities

Significant ( $\mathrm{P}<0.05)$ and negative correlations were observed between the densities of fecal enterococci and the wetted section. The same observation was made between the total flora (BHAM) and the wetted section (Table 6).
} 


\section{Correlations between physicochemical parameters and bacterial abundances}

Correlations between physicochemical parameters and the densities of the isolated bacteria were performed using Spearman's " $r$ " correlation test. It emerges that very significant $(\mathrm{P}<0.01)$ and positive correlations were observed between the densities of total coliforms and parameters such as $\mathrm{pH}$, electrical conductivity. The same observation was obtained between the density of faecal streptococci and the nitrate concentration (Table 7). Significant $(\mathrm{P}<0.05)$ and positive correlations were recorded on the one hand between fecal coliforms and SM content, between faecal streptococci and $\mathrm{pH}$ and between bacteria of the genus Pseudomonas and water turbidity (Table 7). A very significant $(\mathrm{P}<0.01)$ and negative correlation was noted between faecal streptococci and the content of $\mathrm{NH}_{4}{ }^{+}$media (Table 7). Significant (P $<0.05)$ and negative correlations were observed between the densities of bacteria of the genus Pseudomonas and SS, between total coliforms parameters such as temperature and $\mathrm{NH}_{4}{ }^{+}$ content (Table 7).

\section{Comparisons between the variables considered}

The comparison between the physicochemical and microbiological variables during the study period was carried out using the Kruskal-Wallis $\mathrm{H}$ test. From this test, it appears that the physicochemical variables such as: $\mathrm{pH}$, electrical conductivity, nitrates, temperature, SS, have significantly varied during the months of sampling ( $\mathrm{P}<0.05)$. The same observation was made for the densities of bacteria of the genus Pseudomonas.

The Mann Withney comparison test was performed between physicochemical variables, bacterial densities and different months of sampling. It appears that significant differences $(\mathrm{P}<0.05)$ between the $\mathrm{pH}$ and the months of March, April, May, and June; between the electrical conductivities and the month of February; between nitrates and the months of March, May June; between temperature and the month of March; between MES and the months of March and April; between nitrates and the months of February, March, May, and June. The same observations were made between the abundances of bacteria of the genus Pseudomonas and those of February and March. The significance coefficients are presented in Table 8.

\section{Affinities between biotic and abiotic parameters}

The PCR applied to the various biological, physicochemical and hydrological variables shows a grouping of the parameters into 3 nuclei (Figure 7). Core 1 (N1) includes Afamba2 and Lolo stations in which BHAMs maintain strong correlations with nitrates, SM, color, and TDS. In the core (N2) encompassing the Otoundoumba and Afamba1 stations, a strong affinity is observed between temperature, flow, speed, wetted section, and dissolved oxygen. However, there is an absence of bacterial species. Regarding the nucleus (N3) encompassing the Mefomo station, there is a strong presence of bacterial abundances such as fecal enterococci, Pseudomonas, fecal and total coliforms all correlated with electrical conductivity and $\mathrm{pH}$. The strong presence of microorganisms in this station can be explained by the acidic nature of the aqueous support and the rocky nature of the funds.

Table 3: Hydrological parameters of the sampling stations during the study period.

\begin{tabular}{llcccc}
\hline \multirow{1}{*}{ Parameters } & \multicolumn{5}{c}{ Stations } \\
\cline { 2 - 6 } & \multicolumn{1}{c}{ AF I } & MEF & LO & AF II & OTOU \\
\hline Wet Section $\left(\mathrm{m}^{2}\right)$ & 2.76 & 1.62 & 0.84 & 2.56 & 5.33 \\
\hline Speed $(\mathrm{m} / \mathrm{s})$ & 0.155 & 0.22 & 0.153 & 0.124 & 1.76 \\
\hline outflow & 0.42 & 0.35 & 0.128 & 0.317 & 1.76 \\
\hline
\end{tabular}



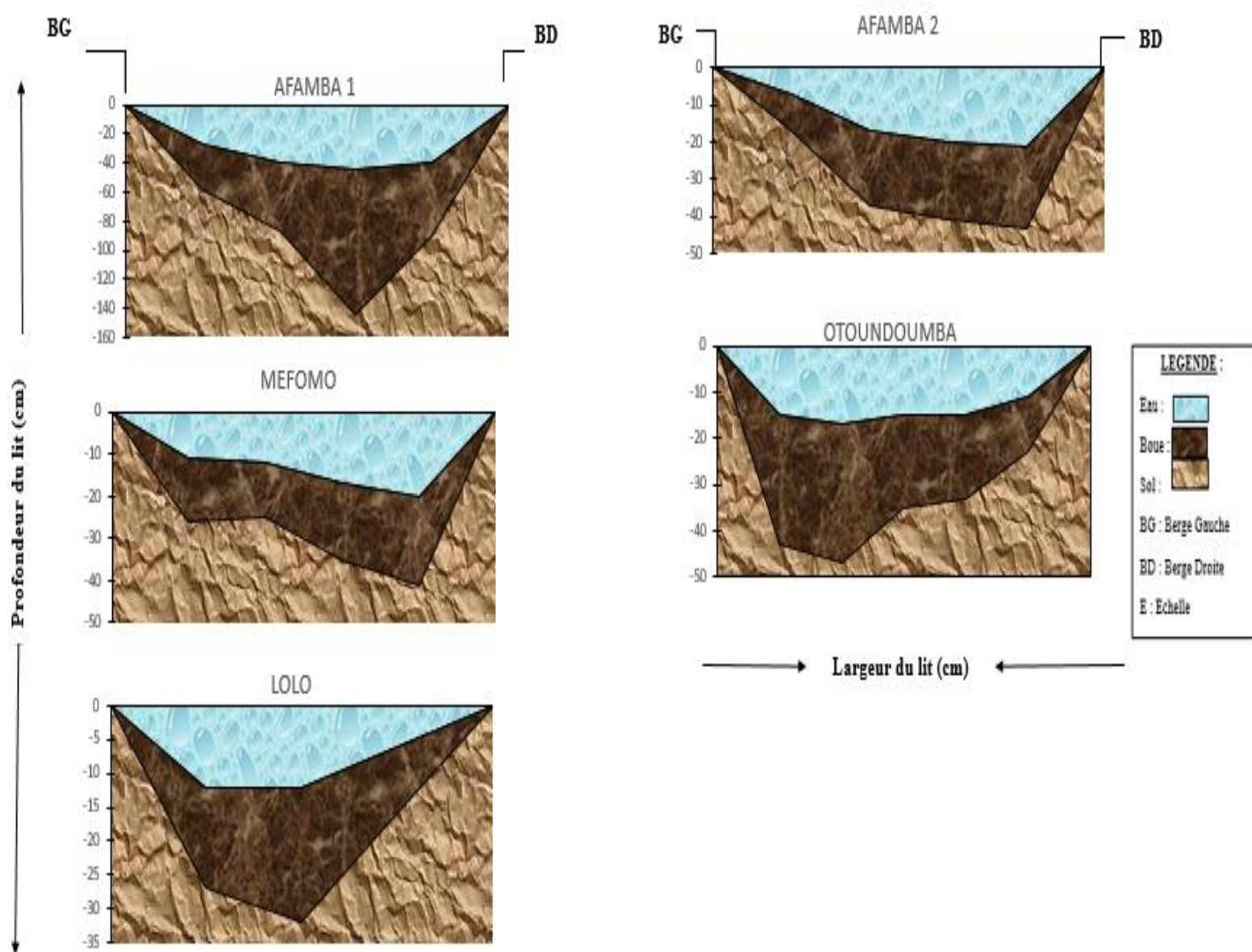

Figure 2: Wet Section of the sampling statins during the study period.

Table 4: presentation of faecal coliform reports on faecal streptococci by sampling station and by month.

\begin{tabular}{lllllll}
\hline Sampling Stations & February & March & April & May & June & July \\
\hline AFAMBA 1 & 0 & 2,95 & 0 & 0 & 0 & 0 \\
\hline AFAMBA 2 & 0,060 & 0,092 & 0,083 & 0 & 0,142 & 0,142 \\
\hline MEFOMO & 0,119 & 0 & 1,880 & 0 & 0,0714 & 0,0714 \\
\hline LOLO & 0 & 0 & 0,004 & 1,728 & 0,051 & 0,051 \\
\hline OTOUNDOUMBA & 0 & 0 & 2,25 & 0 & 1,333 & 1,333 \\
\hline
\end{tabular}



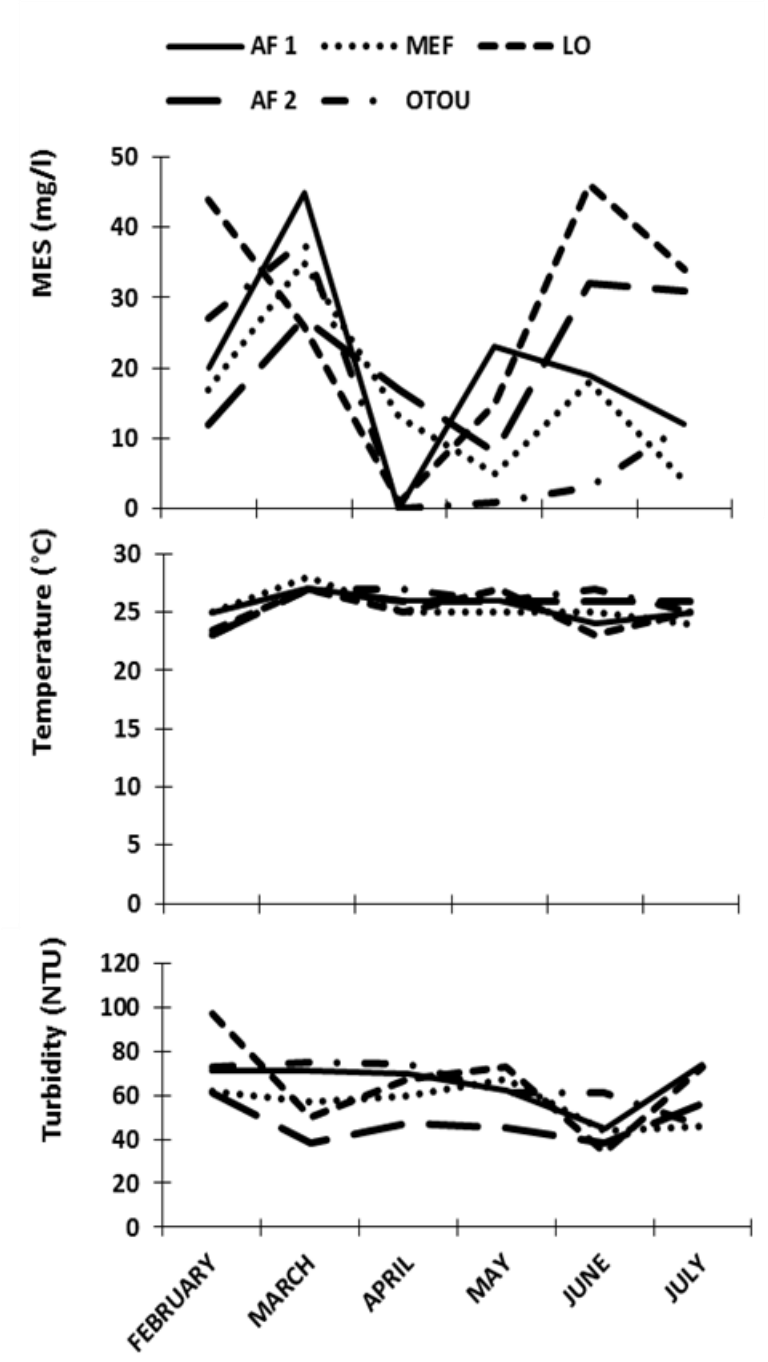
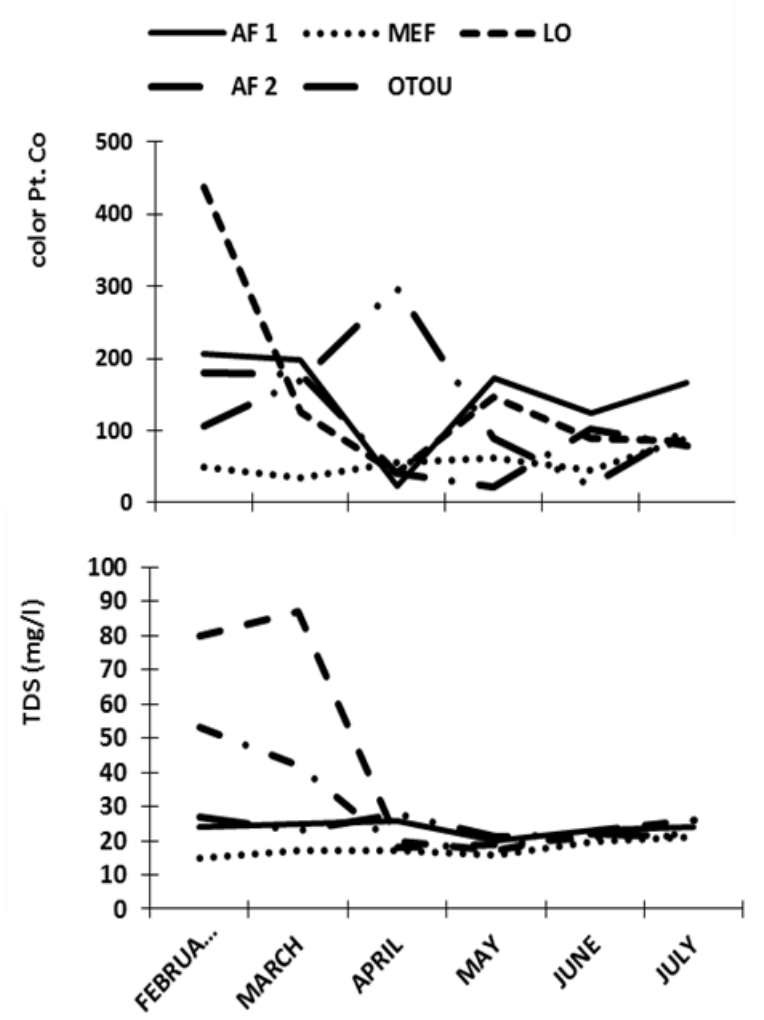

Figure 3: Spatio-temporal variations of the physical parameters measured during the study period (A: SM (suspended matter); B: temperature; C: turbidity, D: color; E: TDS (total dissolved solids). 


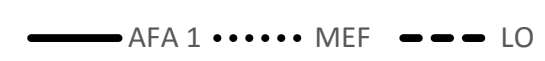

- AFA 2 - • OTOU
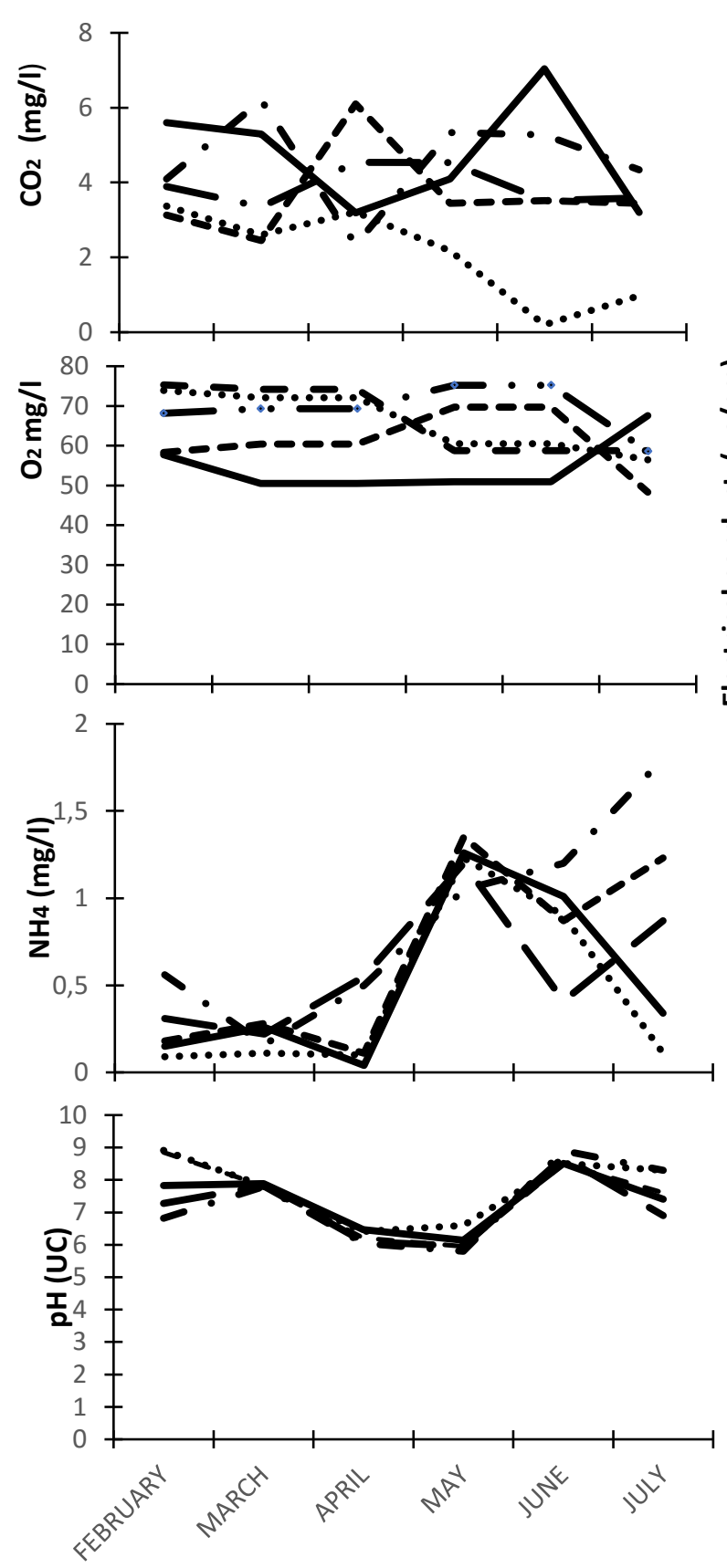
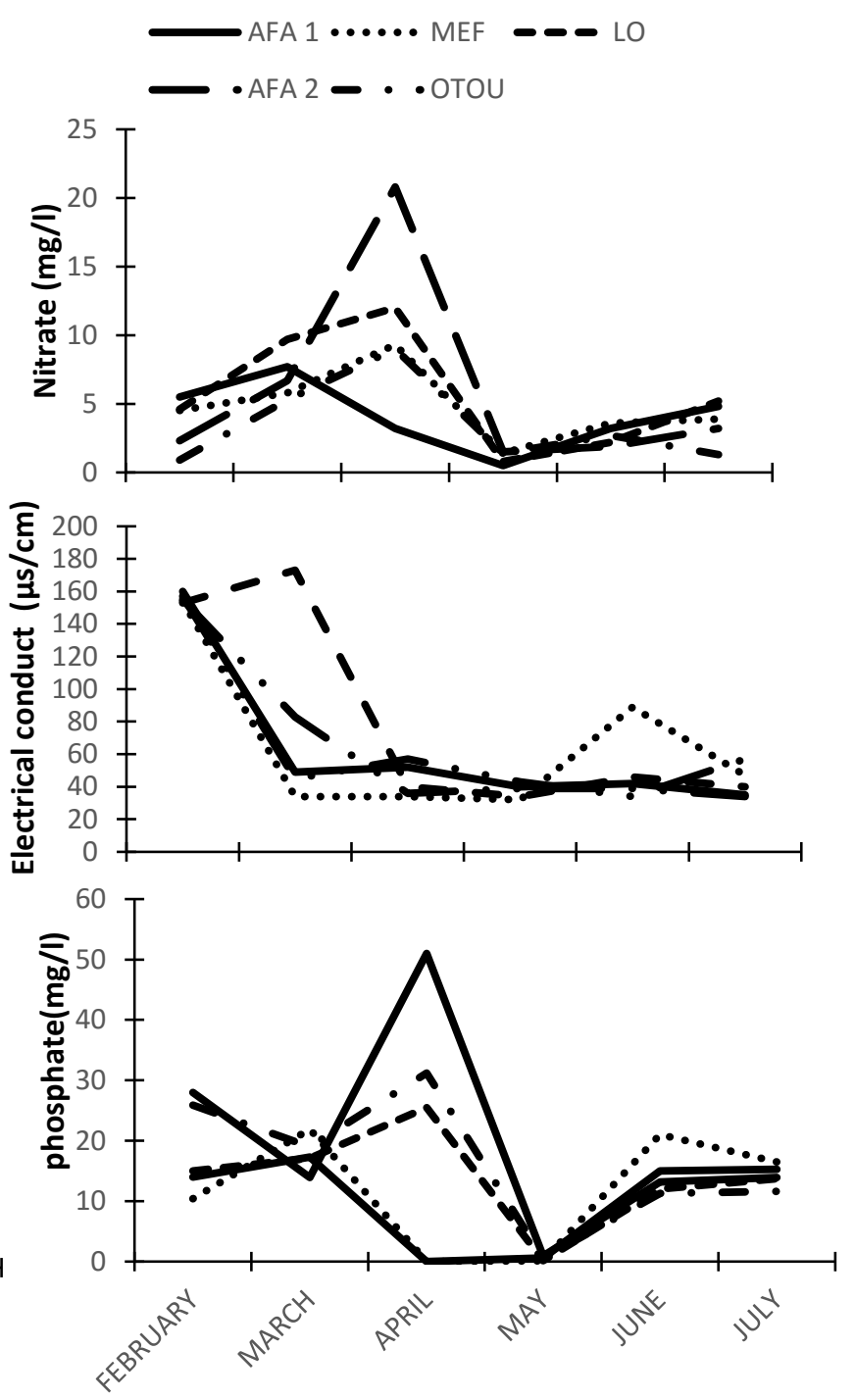

Figure 4: Spatio-temporal variations of the chemical parameters measured during the study period (A: dissolved $\mathrm{CO}_{2}$; B: dissolved oxygen; C: ammoniacal nitrogen $\left(\mathrm{NH}_{4}{ }^{+}\right)$, $\mathrm{D}$ : $\mathrm{pH}$; E: nitrates $\left(\mathrm{NO}_{3}^{-}\right)$ E: electrical conductivity; $\mathrm{G}$ : orthophosphates $\left(\mathrm{PO}_{4}{ }^{3-}\right)$. 


\section{BHAM}

口AF 1 MEF

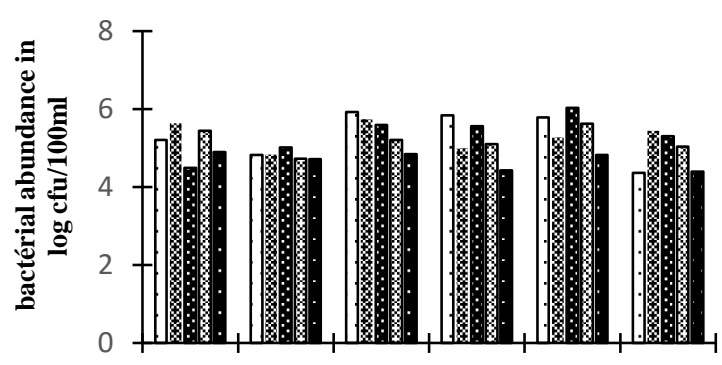

FAECAL ENTEROCOCCI

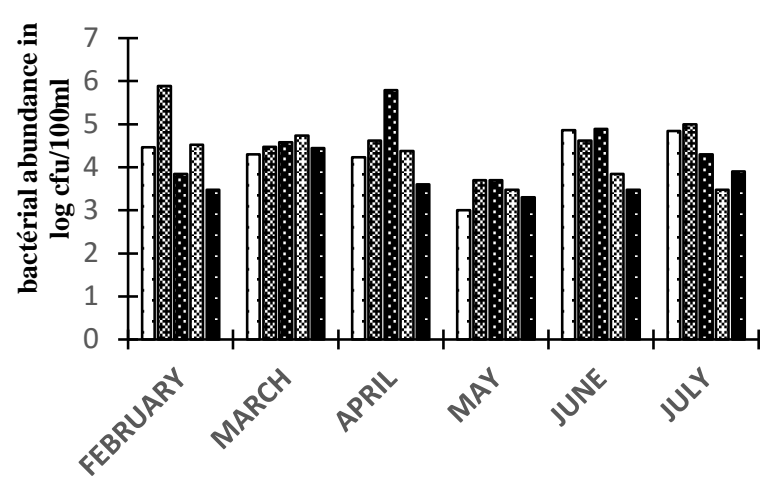

TOTAL COLIFORMS

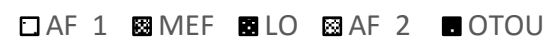

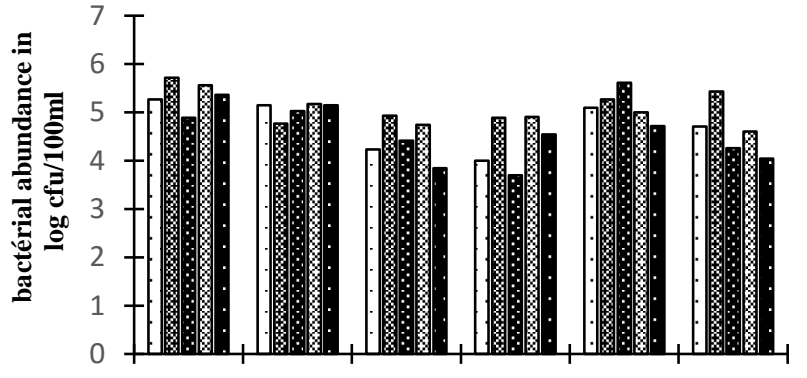

FAECAL COLIFORMS

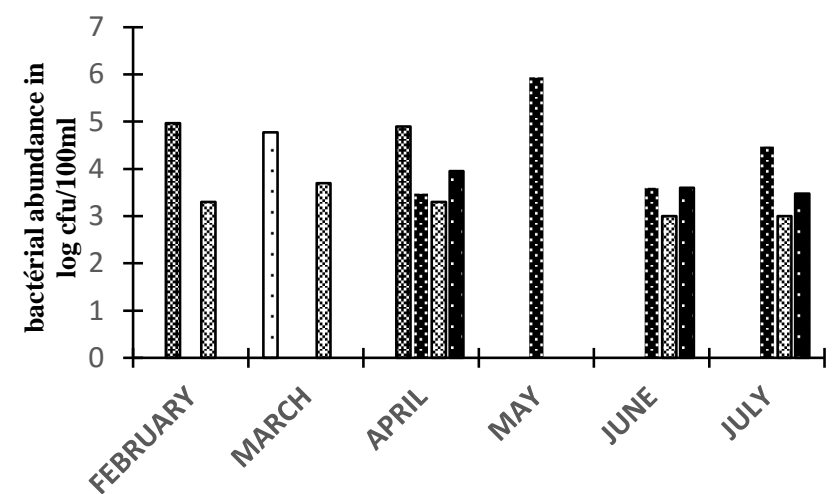

Figure 5: Spatio-temporal evolution of the abundances of bacteria isolated in the Afamba 1, Afamba 2, Lolo, Mefomo and Otoundoumba stations as a function of the months.

Table 5: Results of the identification tests of the strains of Pseudomonas isolated.

\begin{tabular}{|c|c|c|c|c|c|c|c|c|c|c|c|c|c|c|}
\hline \multirow{3}{*}{ Identification test } & \multicolumn{14}{|c|}{ Strains and months } \\
\hline & \multicolumn{3}{|c|}{ Febuary } & \multicolumn{2}{|c|}{ March } & \multicolumn{2}{|c|}{ April } & \multicolumn{2}{|c|}{ May } & \multicolumn{2}{|c|}{ June } & \multicolumn{3}{|c|}{ July } \\
\hline & $\overline{\mathrm{A}}$ & B & $\mathrm{C}$ & $\mathrm{A}$ & $\mathrm{C}$ & B & $\mathrm{C}$ & $\mathrm{A}$ & $\mathrm{C}$ & $\mathrm{A}$ & $\mathrm{C}$ & $\mathrm{A}$ & B & $\mathrm{C}$ \\
\hline Mannitol & + & + & + & + & + & + & + & + & + & + & + & + & + & + \\
\hline Mobility & + & + & + & + & + & + & + & + & + & + & + & + & + & + \\
\hline Lactose & + & + & + & + & + & + & + & + & + & + & + & + & + & + \\
\hline$\overline{\text { Glucose }}$ & + & + & + & + & + & + & + & + & + & + & + & + & + & + \\
\hline King A & + & + & - & + & - & + & - & + & & + & - & + & + & - \\
\hline$\overline{\mathrm{H}_{2} \mathrm{~S}}$ & - & - & - & - & - & - & - & - & - & - & - & - & - & - \\
\hline Citrate & + & + & - & + & - & + & - & + & - & + & - & + & + & - \\
\hline
\end{tabular}




\begin{tabular}{|c|c|c|c|c|c|c|c|c|c|c|c|c|c|c|}
\hline Catalase & - & - & - & - & - & - & - & - & - & - & - & - & - & - \\
\hline suspicious species & $\begin{array}{l}\dot{0} \\
\dot{0} \\
\dot{2}\end{array}$ & $\begin{array}{l}\dot{\vec{j}} \\
\dot{2} \\
\dot{2}\end{array}$ & $\begin{array}{l}\overline{3} \\
\vdots \\
\vdots \\
2\end{array}$ & $\begin{array}{l}\dot{0} \\
\dot{0} \\
\dot{2}\end{array}$ & $\begin{array}{c}\frac{5}{5} \\
\frac{2}{n} \\
2\end{array}$ & $\begin{array}{l}\dot{y} \\
\dot{v} \\
\dot{2}\end{array}$ & $\begin{array}{c}\frac{\pi}{5} \\
\frac{5}{2} \\
2^{n}\end{array}$ & $\begin{array}{l}\dot{y} \\
\dot{z} \\
\dot{2}\end{array}$ & $\begin{array}{c}\frac{5}{\vdots} \\
\frac{\pi}{n} \\
2\end{array}$ & $\begin{array}{l}\dot{y} \\
\dot{v} \\
\dot{2}\end{array}$ & $\begin{array}{c}\overleftarrow{5} \\
\vdots \\
\vdots \\
2 \\
2\end{array}$ & $\begin{array}{l}\bar{y} \\
0 \\
2 \\
2\end{array}$ & $\begin{array}{l}\vdots \\
0 \\
0 \\
2\end{array}$ & $\begin{array}{l}\tilde{b} \\
\vdots \\
\vdots \\
2 \\
2\end{array}$ \\
\hline
\end{tabular}

(+): positive test; (-): negative test; Ps. aer: Pseudomonas aeruginosa; Ps past: Pseudomonas pasteurella.

Table 6: Correlations between hydrological parameters and bacterial abundances.

\begin{tabular}{llllll}
\hline $\begin{array}{l}\text { hydrological } \\
\text { ariables }\end{array}$ & \multicolumn{5}{c}{ microbiological Variables } \\
\cline { 2 - 6 } speed & FT & PS & SF & CF & CT \\
\hline \multirow{2}{*}{ outflow } & $-0,308$ & 0,139 & $-0,123$ & $-0,083$ & $-0,048$ \\
wet Section & $-0,351$ & 0,112 & $-0,207$ & $-0,129$ & 0,033 \\
\hline
\end{tabular}

*: $\mathrm{P}<\overline{0.05} \mathrm{P}=$ degree of significance dof $=14, \mathrm{FT}$ : total flora, PS: Pseudomonas, SF: faecal streptococci, CF: faecal coliforms, CT: total coliforms.

Table 7: Correlations between physicochemical parameters and bacterial density.

\begin{tabular}{lccccc}
\hline \multirow{2}{*}{$\begin{array}{l}\text { Physiochemical } \\
\text { Variables }\end{array}$} & \multicolumn{5}{c}{ Microbiological Variables } \\
\cline { 2 - 5 } $\mathrm{O}_{2}$ & $-0,230$ & 0,198 & 0,144 & $-0,161$ & 0,062 \\
$\mathrm{Ph}$ & $-0,020$ & $-0,256$ & $0,428^{*}$ & 0,081 & $0,537^{* *}$ \\
$\mathrm{TDS}$ & $-0,272$ & $-0,130$ & $-0,009$ & $-0,148$ & 0,133 \\
Conductivity & $-0,051$ & 0,100 & 0,242 & $-0,070$ & $0,481^{* *}$ \\
Colourr & $-0,248$ & 0,094 & $-0,054$ & $-0,137$ & 0,221 \\
Turbidity & $-0,293$ & $0,373^{*}$ & $-0,251$ & $-0,054$ & $-0,320$ \\
Nitrate & $-0,116$ & $-0,051$ & $0,526^{* *}$ & 0,198 & 0,107 \\
Phosphate $_{\text {Temperature }}$ & $-0,259$ & 0,021 & 0,278 & $-0,079$ & 0,263 \\
$\mathrm{CO}_{2}$ & $-0,304$ & $-0,344$ & $-0,323$ & 0,129 & $-0,411^{*}$ \\
$\mathrm{MES}^{*}$ & $-0,038$ & 0,072 & $-0,154$ & $-0,038$ & $-0,009$ \\
$\mathrm{NH}_{4}^{+}$ & $-0,038$ & $-0,401^{*}$ & 0,093 & 0,025 & $0,365^{*}$ \\
\hline
\end{tabular}

*: P <0.05 **: P <0.01 P = degree of significance dof = 5, FT: total flora, PS: Pseudomonas, SF: faecal streptococci, CF: faecal coliforms, CT: total coliforms $* *$ : degree of significance. 
Table 8: $\mathrm{P}$ values indicating the significance thresholds for the KRUSKAL-WALLIS comparison $\mathrm{H}$ test between physicochemical parameters, bacterial abundances and months of sampling.

\begin{tabular}{lc}
\hline $\begin{array}{l}\text { physicochemical and } \\
\text { microbiological } \\
\text { variables }\end{array}$ & $\begin{array}{c}\text { Significance } \\
\text { during the months }\end{array}$ \\
\hline $\mathrm{O}_{2}$ & 0,749 \\
$\mathrm{Ph}$ & $0,001^{*}$ \\
$\mathrm{TDS}$ & 0,105 \\
Conductivity & $0,030^{*}$ \\
Colour & 0,306 \\
Turbiditéy & 0,186 \\
Nitrate & $0,04^{*}$ \\
Phosphate & 0,101 \\
Temperature & $0,016^{*}$ \\
$\mathrm{CO}$ & \\
$\mathrm{MES}$ & 0,805 \\
$\mathrm{NH}^{+}{ }_{4}$ & 0,016 \\
$\mathrm{BHAM}$ & $0,004^{*}$ \\
Pseudomonas & 0,101 \\
Faecal Entérocoques & $0,016^{*}$ \\
$\mathrm{Coliforms} \mathrm{faecal}$ & 0,180 \\
$\mathrm{~T}^{*}$ significant Coliforms $\mathrm{P}<0.05 \mathrm{P}=$ degree of significance & $0,509=5$ \\
\hline
\end{tabular}

* significant at: $\mathrm{P}<0.05 \mathrm{P}=$ degree of significance dof $=5$.

\section{PSEUDOMONAS}

$\square A F 1$ MEF LOAFA 2 DOTOU

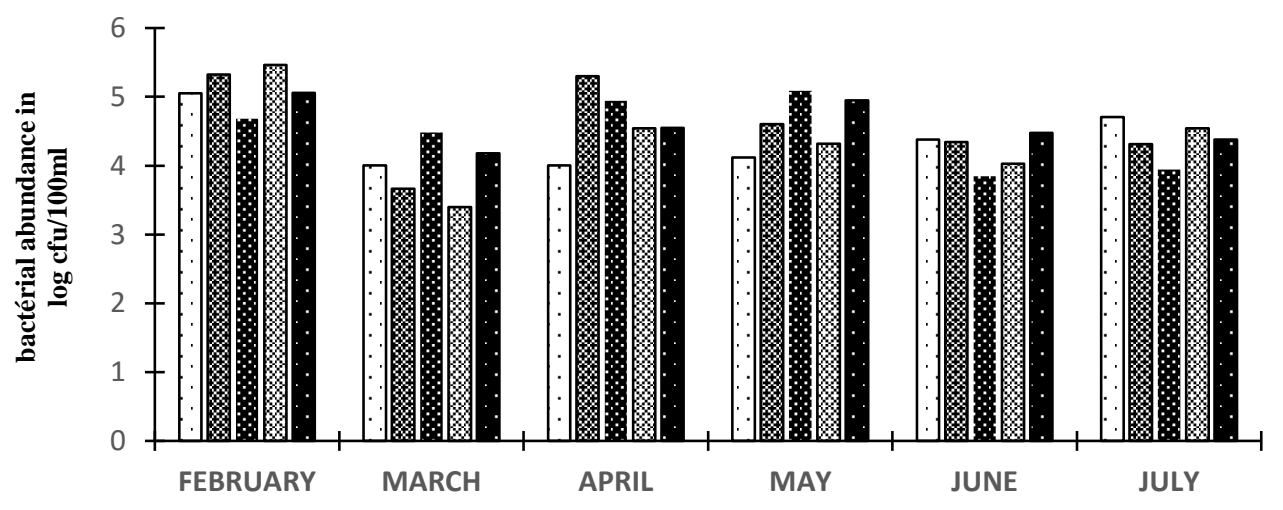

Figure 6: Spatio-temporal variations in the abundance of bacteria. 


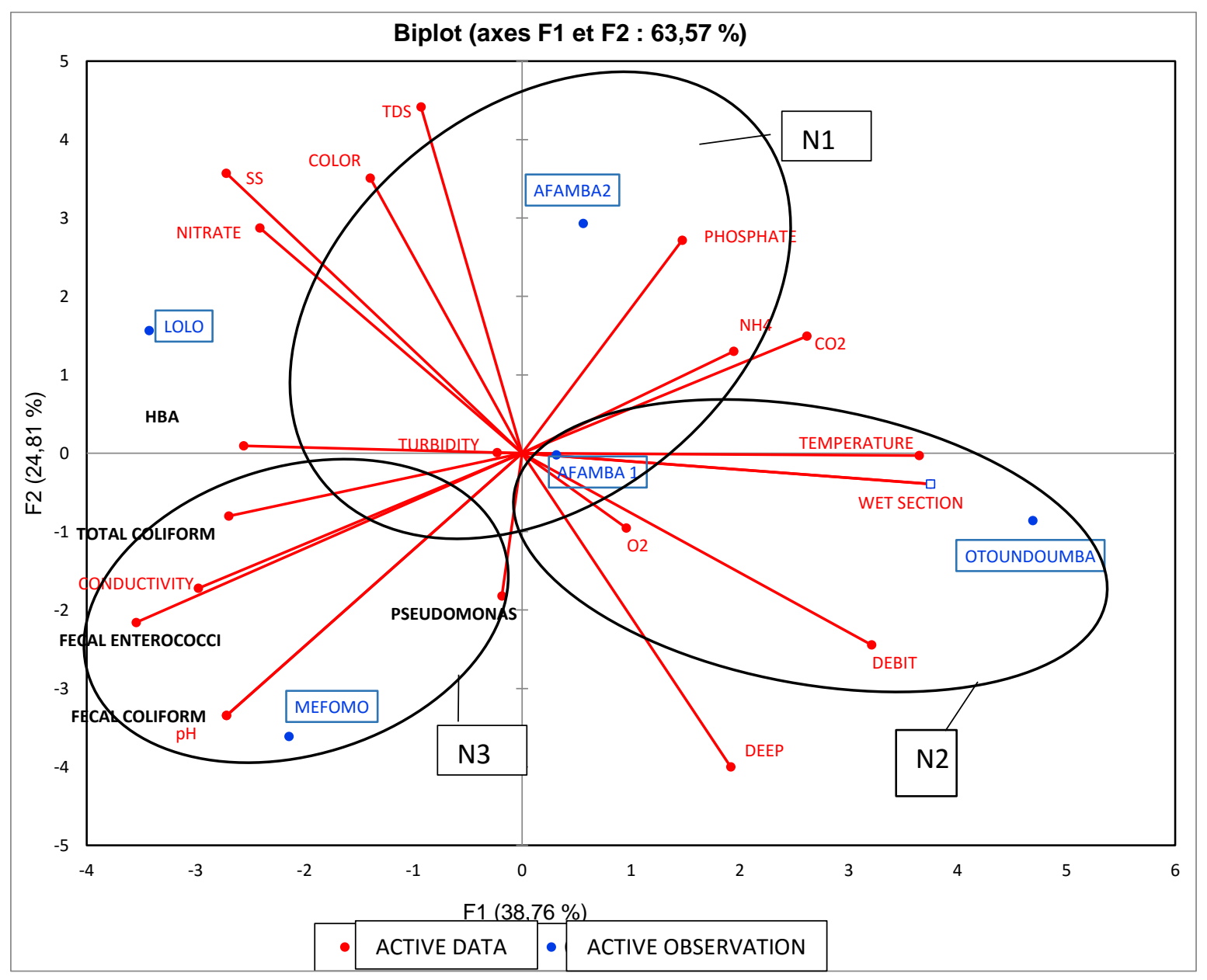

Figure 7: PCR values grouping the affinities between bacterial abundances and physicochemical and hydrological parameters.

\section{DISCUSSION}

\section{Hydrological parameters}

The low speed at Afamba 2 station $(0.124 \mathrm{~m} / \mathrm{s})$ could be explained by its location in a marshy area. The increase in flow and in the wetted section at the Otoundoumba station and the low values of these variables observed at the Lolo station are thought to be due to lateral inflows from the various tributaries. Levêque and Balian (2005) point out in this regard that by receiving small tributaries, the wet section is called upon to increase.

\section{Physico-chemical parameters}

Temperature values vary little from station to station and at the same site, with an average of $25.43{ }^{\circ} \mathrm{C}$. This value is compatible with the activity of local organizations. These results are similar to those obtained by Tuékam Kayo (2007) in the waters of the Mfoundi watershed. This low thermal variation could be explained by the low conductivity of the soil (Ait, 2007).

An average $\mathrm{pH}$ value of $7.04 \pm 1.03$ U.C was recorded. The waters analyzed have a $\mathrm{pH}$ with an acidic tendency, although a value of 8.91 U.C was recorded in the Mefomo station in February. These values obtained would be linked to the low mineralization, the absence of anthropogenic activities, the activity of microorganisms present in the water and the nature of the soils crossed (Nola et al., 2002). 
By considering the quality grid of Nisbet and Verneaux (1970), the stations would present overall a fairly satisfactory saturation in dissolved oxygen $(63.96 \%)$ during the study period. This fairly good oxygenation of the water can be explained by the fairly large plant cover which promotes strong photosynthetic activity releasing oxygen, conducive to oxygenation of the water at the air / water interface. In addition, the strong presence of rafts in the watercourse promotes the resuspension of oxygen molecules (Stark, 2001). These results agree with the assertions of Nechad et al., (2014), Tchakonté (2016) according to which in forest areas, natural ventilation, the presence of rafts and meanders create conditions of turbulence and mechanical mixing favorable to natural ventilation.

The values of the $\mathrm{CO}_{2}$ contents oscillate between 0.2 and $7.04 \mathrm{mg} / \mathrm{L}$. According to Rodier et al. (2009), these levels are influenced by the climate and the seasons, as well as by the nature of the soil and vegetation. The low values of the electrical conductivity of the water from the stations can be explained by the low degradation of the organic matter present in the environment and would reflect the little polluted nature of these waters (Ajeagah et al., 2018). The low average values of SS (19.48 mg / L), color (117.96 Pt-Co) and turbidity (59.93 NTU) recorded in the stations are explained by the low load of the water in organic matter and the low intake of allogenic materials in water bodies. The low values of these parameters are similar to those obtained by Foto Menbohan et al. (2013) on the Nga and Tchakonté et al. (2016) in the peri-urban area of Douala. The SS values recorded would reflect an absence of anthropogenic pollution. The value of $46 \mathrm{mg} /$ L observed in June at the Lolo station could be explained on the one hand by the nature of the substrate and on the other hand by the decomposition of the organic matter and in particular of the litter which releases the humic acids and colloidal substances. The maximum value of turbidity in February in Lolo could be due to the return of the rains. The relatively low concentrations of nitrate, $(0.5-20.8 \mathrm{mg} / \mathrm{L})$ of ammoniacal nitrogen $(0.04-1.8 \mathrm{mg} / \mathrm{L})$ and orthophosphates ( 0 -21.9 mg / L) would be due to the low mineralization of waters and the little anthropized nature of the study area. This result is similar to that obtained by Tuekam Kayo (2007).

\section{Biological parameters}

In general, BHAM were present at all stations throughout the study period and dominate the identified bacterial community. Indeed, according to Levallois and Levesque (2003), the enumeration of the aerobic bacterial flora aims to estimate the density of the general bacterial population. The high abundance could be due to the fact that the environment of these stations is favourable for their development. In addition, the high bacterial load of BHAM recorded could also be due to contaminated runoff. According to Foster and Salas (1991) this factor favors the contamination of surface and underground water, causing bacteria to move. This contamination, however, depends on the pollutant load of the contaminant and the permeability of the overlying soil.

Among the main groups of bacteria indicative of faecal contamination, those represented are: total coliforms, faecal coliforms and faecal streptococci. The abundances of these groups of bacteria have varied from station to station and over time. The mean values of the abundances recorded are $4.93 ; 1.92$ and $4.25 \log \mathrm{CFU} / 100 \mathrm{~mL}$ for fecal coliforms, total coliforms and faecal streptococci, respectively. These values are all above the standards set by the WHO. This therefore indicates a deterioration in the bacteriological quality of the water (WHO, 2004). This predominantly animal contamination occurs upstream in the Afamba stream which serves as a watering point for herds in the locality of Obala (Lekié Department, Center Region). The waters of Nkolafamba also harbor a pathogenic microflora, with in particular bacteria such as $P$. aeruginosa, $P$. pasteurella, and the abundances of which can sometimes reach $5.462 \log$ CFU / $100 \mathrm{~mL}$. These germs can cause eye infections or sepsis on users of these waters (WHO, 2004). The permanent presence 
of these pathogenic bacteria and their high abundance reflects the degree of pollution of these waters. Similar results have been obtained in particular by Mpakam et al. (2006) in Bafoussam where many pathogens such as Escherichia coli, Salmonella, Shigella and many other bacteria witnessing faecal contamination have been observed there. The same is true of the results obtained by Nanga et al. (2014) in Yaoundé and Ndjama et al. (2011) in Douala. These authors, having analyzed the drinking water, isolated bacteria indicative of faecal contamination and strict pathogenic and opportunistic bacteria.

\section{Links between the evaluated parameters}

The results of the correlations between the physicochemical and biological variables show that among the physicochemical parameters analyzed, certain variables significantly influenced the population and the distribution of bacteria throughout the study. Increasing the $\mathrm{pH}$ of the water significantly increases the abundance of fecal and total coliforms, and fecal enterococci. In this regard, Nola et al. (2002) are of the opinion that in a given medium, increases in $\mathrm{pH}$ sometimes favor the development of Pseudomonas aeruginosa, Aeromonas hydrophila, as well as the abundance of fecal coliforms and faecal streptococci.

The level of nitrate and SM which is significantly positively correlated with the abundance of faecal enterococci. The increase in the content of SM leads to a significant increase in the density of fecal coliforms and a significant decrease in bacteria of the genus Pseudomonas. This difference would result in the fact that bacteria react differently to organic matter and depending on the composition of the latter. Indeed, organic matter influences the availability of nutrients while serving at the same time as a source of energy and carbon for certain microorganisms (Nola et al., 2004).

Increasing the temperature significantly decreases the abundance of bacteria of the genus Pseudomonas. This could be explained by the fact that solar radiation has a bactericidal action on aquatic bacteria (Lopez-Pila and Szewzyk, 2000). They also have the effect of warming the water and consequently contribute to the decrease in the number of microorganisms (Rodier et al., 2009). However, these results are similar to those of the work of Seni (2013) which showed that a high temperature would induce in bacteria alterations in cellular structures, thus promoting entry into a viable but noncultivable state.

\section{COMPETING INTERESTS}

The authors declare that there is no competing interests.

\section{AUTHORS' CONTRIBUTIONS}

The coaches contributed to the design and planning of the experiments. SDB, AAT, CSM, YPY performed analyzes under the supervision of OVNE, MN. OVNE, SDB, RTK and DE wrote the manuscript. All authors have approved the final version of the manuscript.

\section{ACKNOWLEDGMENTS}

The Author acknowledge the Council of city of Nkolafamba town that requested and funded part of this work.

\section{REFERENCES}

Ait B, Yacoubi-Khebiza M, Boulanouar M, Boutin C, Messana G. 2007. Qualité des eaux souterraines dans deux régions arides du Maroc : impact des pollutions sur la biodiversité et implications paléogéographiques. Environmental Technology, 28: 1299-1315. DOI: https://doi.org/10.1080/09593330802180 237

Ajeagah A, Mbainaissem M, Njawouo P, Ngakomo A. 2018. Caractérisation physicochimique et biologique en zone péri urbaine en Afrique équatoriale : cas de Ngoumou au centre du Cameroun. International Journal of Innovation and Applied Studies, 23: 33.

Chuzeville B. 1990. Hydrobiologie tropicale et appliquée en Afrique subsaharienne. Agridoc, Collection maîtrise de l'eau, ministère français de la coopération et du développement, Paris, $275 \mathrm{P}$. 
Foto M, Tchakonté S, Ajeagah G, Zébazé T, Bilong B, Njiné T. 2013. Water quality assessment using benthic macroinvertebrates in a periurban stream (Cameroon). The International Journal of Biotechnology, 2: 91-104.

Foster S, Salas H. 1991. Identification et classement des risques de pollution des eaux superficielles et souterraines: $\mathrm{La}$ gestion qualitative des eaux dans les pays en développement (critères et approches). Ressources Naturelles, 26: 105-111.

George I, Sevais. 2002. Sources et dynamique des coliformes dans le bassin de la Seine. Centre National de la Recherche Scientifique, Paris, France, 46 p.

Hébert S, Légaré S. 2000. Suivi de la qualité des rivières et petits cours d'eau. Envirodoq No ENV-2001-0141, rapport $\mathrm{N}^{\circ} \mathrm{E}-123$, Direction du suivi de l'état de l'environnement, ministère de l'environnement, Québec, 24 p.

Holt J, Krieg N, Sneath P, Staley J, Williams S. 2000. Bergey's Manual of Determinative Bacteriology. Lipponcott Williams and Wilkins: Philadelphia.

Kuete M, Dikoume A, Elong G. 2004. Aperçu historique et population actuelle. Commune rurale, Soa-Cameroun, $48 \mathrm{p}$.

Lévêque C, Balian E. 2005. Conservation of freshwater Biodiversity: does the real world meet scientific dream? Hydrobiologia, 542: 25-26. DOI: 10.1007/s10750-005-0891-0.

Lopez-Pila J, Szewzyk R. 2000. Estimating the infection risk in recreational waters from the faecal indicators concentration and from the ratio between pathogens and indicators. Water Research, 34: 41955200.

DOI:

https://doi.org/10.1016/S00431354(00)00197-4

Marchal N, Bourdon J, Richard C. 1991. Les Milieux de Culture pour L'Isolement et l'Identification Biochimique des Bactéries. Dion-biologie appliquée : Paris.

Mezaache S. 2012. Localisation des déterminants de la suppression de quelques souches de Pseudomonas isolées de la rhizosphère de la pomme de terre. Thèse, Université de Toulouse, P. 19.

Mpakam H, Kouam K, Jean-loup B, Ekodeck G, Bernard D. 2006. Etude des facteurs de pollution des ressources en eau en milieu urbain : cas de Bafoussam (Ouest, cameroun).

https://www.google.fr/search/Mpakam/ét ude (download February $2^{\text {nd }}, 2017$ ).

Moungang L, Nola M, Nougang M, Noah E, Krier F, Servais P. 2013. Abundance of heterotrophic aerobe bacteria (HAB) adsorbed on Granite, Basalt and Migmatite rock fragments immersed in wells in Central Africa: Temporal variation and assessment of the hierarchical influence of some abiotic factors. International Journal of Research in BioSciences, 2(2): 13-25.

Nanga N, Ngene J, Tsala DE, Ngoule C, Lamare N. 2014. Relation entre Pollution des Eaux de Sources, Forages et Maladies Hydriques Enregistrées au Centre Hospitalier Dominicain Saint Martin de Porres (CHDSMP) du Quartier MvogBetsi à Yaoundé. Health Sciences and Diseases, 15(3): 1-8.

Ndjama J, Kuitcha D, Awah T, Beyala K, Nkamdjou S, Ekodeck E. 2011. Richesse spécifique et abondanc e bactérienne dans deux bassins versants (Mgoua et Bobongo) à Douala (Cameroun). Journal Africain des Science de l'Environnement, 2(12): 71-83.

Nechad I, Fadil K, Fadil. 2014. Qualité physicochimique des eaux des sources Ain Regrag et Ain Sidi Bouali dans la région de Sefrou (Moyen Atlas, Maroc). Larhyss Journal, 20: 127-146.

Nisbet M, Verneaux J. 1970. Composante chimique des eaux courantes discussion et proposition des classes en tant que base d'interprétation des cours d'eau Français. Annls Limnol., 6(2): 161-190. DOI: https://doi.org/10.1051/limn/1970015

Nola M, Njiné T, Djuikom E, Sikati F. 2002. Faecal coliforms and faecal streptococci community in the underground water in an equatorial area in Cameroon (Central 
Africa): the importance of some environemental chemical factors. Water Research, 36: 3289-3297. DOI: 10.1016/s0043-1354(02)00024-6.

Nola M, Njiné T, Boutin C, Messouli M, Servais P, Foto Menbohan S, Ngo Bidjeck, Zébazé T, Kemka N. 2004. Retention of Escherichia coli from water infiltration in the equatorial soil in Cameroon (Central Africa): The role of various soil layers. Journal of Cameroon Academy of Sciences, 2: 107-116.

Nola M, Noah E, Nougang M, Moungang M, Chihib N, Krier F, Servais P, Hornez J, Njine T. 2010. Involvement of cell shape and flagella the bacterial in retention during percolation of contaminated water through soil columns in tropical region. Journal of Environmental Science and Health, 45(11): 1297-1306. DOI: 10.1080/10934529.2010.500877.

OMS. 2004. Directives de qualité pour l'eau de boisson, critères d'hygiène et documentation à l'appui. OMS, Genève, Suisse.

Rodier J, Legube B, Merlet N. 2009. L'Analyse de l'Eau (9e edn). DUNOD: Paris.

Seni A. 2013. Effect of the temperature on the growth of Enterococcus faecalis cultivated in alkaliphilic conditions using hydrolyzed sago starch. Thesis in resource science and Technology, University Malaysia Sarawak.
Suchel F. 1987. Les régions climatiques du Cameroun : Les climats du Cameroun. Travaux de Géographie Tropicale, 5: 2429.

Stark H. 2001. Arrangement of RNA and proteins in the spliceosome small ribonucleoprotein particle. Nature, 409(6819): $539-542 . \quad$ DOI: $10.1038 / 35054102$

Tchakonté S. 2016. Diversité et structure des peuplements de macroinvetébrés benthiques des cours d'eau urbains et périurbains de Douala (Cameroun). Thèse de Doctorat/ph.D en biologie des organismes animaux, Université de Yaoundé I, $179 \mathrm{p}$.

Tuekam K. 2007. Stygofaune de deux bassins versants souterrains contigus de la région de Yaoundé : influence de la pression Anthropique. Mémoire DEA de Biologie Animale, Université de Yaoundé I, 69 p.

Vallerie M. 1973. Contribution à l'Etude des Sols du Centre-Sud Cameroun. Types de Différenciation Morphologique et Pédologie sous Climat Subéquatorial. Edition de L'ORSTOM, Paris.

Zébazé T, Tuékam K, Boutin C, Nola M, Foto S. 2011. Impact de la pression anthropique sur l'eau et la faune aquatique des puits et sources de la région de Yaoundé (Cameroun, Afrique Centrale). Bulletin de la Société d'Histoire Naturelle de Toulouse, 147: 27-41. 